Research article

urn:1sid:zoobank.org:pub:9B28E649-8CB4-4125-98F8-E467F24CBE3C

\title{
A new species of Novastoa Finlay, 1926 (Mollusca: Gastropoda: Vermetidae) from coral reefs of the Pacific Ocean
}

\author{
Stefano SCHIAPARELLI I,*, Rüdiger BIELER ${ }^{2}$, Rosemary E. GOLDING ${ }^{3}$, \\ Timothy A. RAWLINGS ${ }^{4} \&$ Timothy M. COLLINS ${ }^{5}$ \\ ${ }^{1}$ Dipartimento di Scienze della Terra dell'Ambiente e della Vita (DISTAV), Università di Genova, \\ C.so Europa 26, 16132 Genova, Italy and Museo Nazionale Dell'Antartide (MNA), \\ Viale Benedetto XV N ${ }^{\circ}$ 5, 16132 Genova, Italy. \\ ${ }^{2,3}$ Integrative Research Center, Field Museum of Natural History, \\ 1400 Lake Shore Drive, Chicago, Illinois 60605, USA \\ ${ }^{3}$ University of Sydney, NSW 2006, Australia. \\ ${ }^{4}$ Department of Biology, Cape Breton University, 1250 Grand Lake Road, \\ Sydney, Nova Scotia B1P 6L2, Canada. \\ ${ }^{5}$ Department of Biological Sciences, Florida International University, \\ 11200 SW $8^{\text {th }}$ St., Miami, Florida 33199, USA \\ *Corresponding author: Stefano.schiaparelli@unige.it \\ 2Email: rbieler@fieldmuseum.org \\ ${ }^{3}$ Email: rosemary.e.golding@gmail.com \\ ${ }^{4}$ Email: Timothy_Rawlings@cbu.ca \\ ${ }^{5}$ Email: CollinsT@,fiu.edu \\ ${ }^{1}$ urn:lsid:zoobank.org:author:D5CF0ED9-9A7C-45D4-B4E1-895D56CA160A \\ ${ }^{2}$ urn:lsid:zoobank.org:author:1D69ADE5-5ABF-43C7-A766-DD65FA7629CB \\ ${ }^{3}$ urn:lsid:zoobank.org:author:B81291AA-13E1-43E9-920B-6FD613D8AAEA \\ ${ }^{4}$ urn:lsid:zoobank.org:author:5EFCC25B-EDA1-46DB-8347-28A4D8763880 \\ ${ }^{5}$ urn:1sid:zoobank.org:author:266E26AA-9350-41C4-BEE8-36E7E7CA4DA4
}

\begin{abstract}
A new species of vermetid gastropod belonging to the genus Novastoa Finlay, 1926, N. rapaitiensis sp. nov., is described from French Polynesia and the Great Barrier Reef, based on morpho-anatomical and molecular data, increasing the recognized extant diversity of this genus from five to six species. The new species is characterized by the largest operculum in the genus to date, with a conspicuous spindle-shaped mammilla that readily distinguishes this species from its congeners. Based on available data, members of the studied populations of $N$. rapaitiensis sp. nov. are interpreted as a single species, although slight morphological and color differences exist between localities separated by up to $7000 \mathrm{~km}$. The larval development of $N$. rapaitiensis sp. nov. is inferred to be direct, raising new questions about genetic connectivity and dispersal trajectories across a vast geographic range. Additional molecular data may prove helpful in refining our current knowledge on the morphological variability within this species and verifying the degree of cryptic diversity in this genus.
\end{abstract}

Keywords. Vermetidae, Novastoa rapaitiensis sp. nov., Pacific Ocean, taxonomy, morphology. 
Schiaparelli S., Bieler R., Golding R.E., Rawlings T.A. \& Collins T.M. 2017. A new species of Novastoa Finlay, 1926 (Mollusca: Gastropoda: Vermetidae) from coral reefs of the Pacific Ocean. European Journal of Taxonomy 323: 1-11. https://doi.org/10.5852/ejt.2017.323

\section{Introduction}

Vermetidae is a family of caenogastropods characterized by a sessile habit and uncoiled shells whose taxonomy has remained in a state of flux for decades due to their highly variable shell features.

There are close to 300 existing names available for extant vermetid species (Bieler \& Petit 2011). The majority of the species descriptions are limited to shell features, with a general lack of information on the soft parts and other features of the living animals.

Golding et al. (2014) revised the genus Dendropoma Mörch, 1861 (s. lat.), both from a molecular and morphological point of view, and recognized 21 extant species (of which eight were described as new), distributed into four genera: Dendropoma s. str., Novastoa Finlay, 1926, Ceraesignum Golding et al., 2014, and Cupolaconcha Golding et al., 2014. All four genera were strongly supported in a molecular phylogenetic analysis of select vermetid taxa in Golding et al. (2014), with Dendropoma and Ceraesignum forming a robust monophyletic grouping, and with Novastoa and Cupolaconcha more closely related to other vermetid groups.

All these genera are characterized by markedly different and elaborated opercula, with Novastoa standing as an extreme case, with the conical, concave, and thick opercula bearing a conspicuous nipple- or spindle-shaped mammilla on the body side. The function of this 'oversized' mammilla is unknown, but could reasonably represent an aid in preventing operculum removal by predators (Golding et al. 2014).

In this contribution we describe a new species of Novastoa, N. rapaitiensis sp. nov., from French Polynesia and the Great Barrier Reef, with the largest known, spindle-shaped development of the mammilla on the operculum.

\section{Material and methods}

The following abbreviations (same as in Golding et al. 2014) are used in the figures:
an $=$ anus
$\mathrm{cm}=$ columellar muscle
$\mathrm{cr}=$ cartilaginous rod
ct $=$ cephalic tentacle
es $=$ esophagus
$\mathrm{fg}=$ food groove
gi $=$ gill
mo $=$ mouth
op $=$ operculum
os $=$ osphradium
ov $=$ ovary
po $=$ pallial oviduct
re $=$ rectum
$\mathrm{sr}=$ seminal receptacle
$\mathrm{sv}=$ seminal vesicle 
Abbreviated names of institutions:

$\mathrm{AM} \quad=$ Australian Museum, Sydney, Australia

FMNH $=$ Field Museum of Natural History, Chicago, Illinois, USA

MNHN = Muséum national d'Histoire naturelle, Paris, France

UF $\quad=$ Florida Museum of Natural History, Gainesville, Florida, USA

\section{Sample collection}

Type material of the new species described herein comes from extensive collections made in the framework of the Rapa 2002 workshop organized by the Université de Polynésie française, the École pratique des hautes Études (EPHE), the Institut de Recherche pour le Développement (IRD) and the Muséum national d'Histoire naturelle of Paris (MHNN) with the aim of characterizing the marine (Lozouet et al. 2004, 2005) and terrestrial fauna and flora (Englund 2003) of the Island of Rapa (Austral Islands, South Pacific). The expedition took place between October 27 and December 10, 2002. These specimens were collected by S. Schiaparelli. Additional samples studied were collected at Moorea Island (French Polynesia) by G. Paulay, T. Lotufo and S. McPherson in 2006 and 2009. Further samples that can be ascribed to the new species come from the Australian Museum (Sydney) collections and were collected in 1975 along the Great Barrier Reef by P. Hutchings and P. Weate.

\section{Laboratory analyses}

Living specimens were extracted from their shells, photographed with a digital camera attached to a stereo microscope and then fixed in $95 \%$ ethanol for molecular analyses or in $4 \%$ formalin for anatomical study. Radulae and opercula were dissected from the buccal mass, soaked in $10 \% \mathrm{NaOH}$ solution and rinsed in distilled water. Whenever necessary to remove debris and incrustations, e.g., from opercula, an ultrasonic water bath was used. For SEM observation, radulae, opercula and protoconchs were dehydrated in progressive concentrations of ethanol, mounted on stubs, gold sputtered, and observed with a Leica/Leo Stereoscan S440 ESEM (University of Genova) or a Leo EVO 60 SEM (FMNH). Gross anatomy was sketched using a drawing tube attachment. Measurements of hatchling protoconch height were performed by using ImageJ (https://imagej.nih.gov/ij/) on SEM images.

\section{Results}

Phylum Mollusca Linnaeus, 1758

Class Gastropoda Cuvier, 1795

Subclass Caenogastropoda Cox, 1960

Superfamily Vermetoidea Rafinesque, 1815

Family Vermetidae Rafinesque, 1815

Genus Novastoa Finlay, 1926

Novastoa rapaitiensis sp. nov. urn:1sid:zoobank.org:act:CDFD584C-298A-4360-ADAE-09F8220E49B0

Figs 1-3

Novastoa sp. - Golding et al., 2014: 8 (table 1), 14, fig. 6 (phylogram), 82, 90, fig. 353 (cross-sectional diagram of operculum). 


\section{Etymology}

This species takes the name of its type locality, Rapa Iti Island (French Polynesia), and is dedicated to all the people from Rapa Iti that we met during the MNHN Rapa 2002 Expedition, in recognition of their kindness and hospitality.

\section{Material Examined}

\section{Holotype}

FRENCH POLYNESIA: $\widehat{o}$ ( 1 complete body and shell fragments), RAPA 2002 Expedition, st. 2, Bass

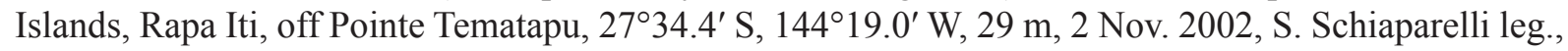
95\% EtOH (MNHN IM-2000-27249).

\section{Paratypes}

FRENCH POLYNESIA: 1 ? ? (1 anterior body, dissected for operculum and tissue clipping), same collection data as holotype, 95\% EtOH (GenBank acc. nr. KC583404.1 (28S ribosomal RNA gene, partial sequence; 12S ribosomal RNA gene, partial sequence; tRNA-Val gene, complete sequence), nr. KC583373.1 (16S ribosomal RNA gene, partial sequence)) (MNHN IM-2000-31684); 1 ㅅ, 2 우 (incomplete specimens with part of viscera missing, extracted from dead coral blocks), RAPA 2002

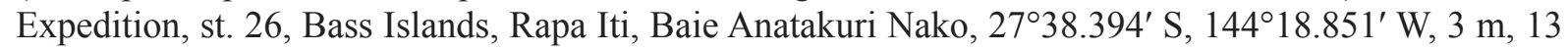
Nov. 2002, S. Schiaparelli leg., formalin fixed and transferred to 95\% EtOH (MNHN IM-2000-31685).

\section{Additional material}

FRENCH POLYNESIA: 1 specimen, Society Islands, Moorea Island, E of Cook's Bay, 17²8.434' S, $149^{\circ} 49.116^{\prime} \mathrm{W}, 11 \mathrm{~m}$, fore reef in groove and under rocks, 1 Nov. 2009, G. Paulay, T. Lotufo and S. McPherson leg., 75\% EtOH (UF 436684); 1 specimen, Society Islands, Moorea Island, fore reef between Cook's and Opunohu Bays, $17^{\circ} 28.632^{\prime} \mathrm{S}, 149^{\circ} 49.836^{\prime} \mathrm{W}$, in coralline pavement, 0-2 m, 6 July 2006, G. Paulay leg., 75\% EtOH (UF 400881); several specimens (only photographs examined, Fig. $1 \mathrm{~A}-\mathrm{C}, \mathrm{F}$ ), same collection data as preceding, $0 \mathrm{~m}, 10 \%$ formalin fixed and transferred to $75 \% \mathrm{EtOH}$ (UF 400847, UF 400849).

AUSTRALIA: many bodies, all without shells, Great Barrier Reef, Queensland, Yonge Reef, inner reef, $14^{\circ} 35.100^{\prime} \mathrm{S}, 145^{\circ} 37.020^{\prime} \mathrm{E}$, on dead branching coral, 3 m, Jan. 1975, P. Hutchings and P. Weate leg., $5 \%$ formalin (AM C.464342).

\section{Description}

Teleoconch. Apertural diameter to $2.3 \mathrm{~mm}$, diameter of expanded 'chamber' behind aperture up to $4.1 \mathrm{~mm}$; diameter of last whorl up to $10.4 \mathrm{~mm}$. Up to 3 whorls coiled concentrically; entirely embedded in substrate (including dorsal surface of shell) with only aperture visible (Fig. 1A); aperture flush with or countersunk below surface. Shell very thin, delicate. External surface entirely surrounded by substrate matrix, but white when cleaned; sculpture of very low transverse lamellae (Fig. 2M). Interior surface white with transverse stripe of brown on columellar surface of last whorl (in 'chamber') (Fig. 1B-C).

Protoconch (Fig. 2A-D). Hatchling protoconch height $657.27 \pm 40.27 \mu \mathrm{m}$ (mean $\pm \mathrm{SD}, \mathrm{n}=3$ ), diameter $561.94 \pm 47.89 \mu \mathrm{m}(\mathrm{mean} \pm \mathrm{SD}, \mathrm{n}=4)$. Sculpture absent on first whorl, then consisting of up to 14 heavy axial ribs. Space between ribs about 3 times rib width. According to developmental stage, protoconchs may be yellow to brown in color (Fig. 1M), with latter stage approaching that of fully developed protoconch in number of whorls and development of labrum.

Operculum (Fig. 1G-L). Diameter up to $3 \mathrm{~mm}$ (Rapa Iti), $2.5 \mathrm{~mm}$ (Moorea) or $1.9 \mathrm{~mm}$ (Yonge Reef). Orange cream white peripherally, with a reddish band toward external edge (Fig. 1D-E, G); formalin fixed material turns whitish, but some specimens retaining reddish band close to edge. Lamina on 

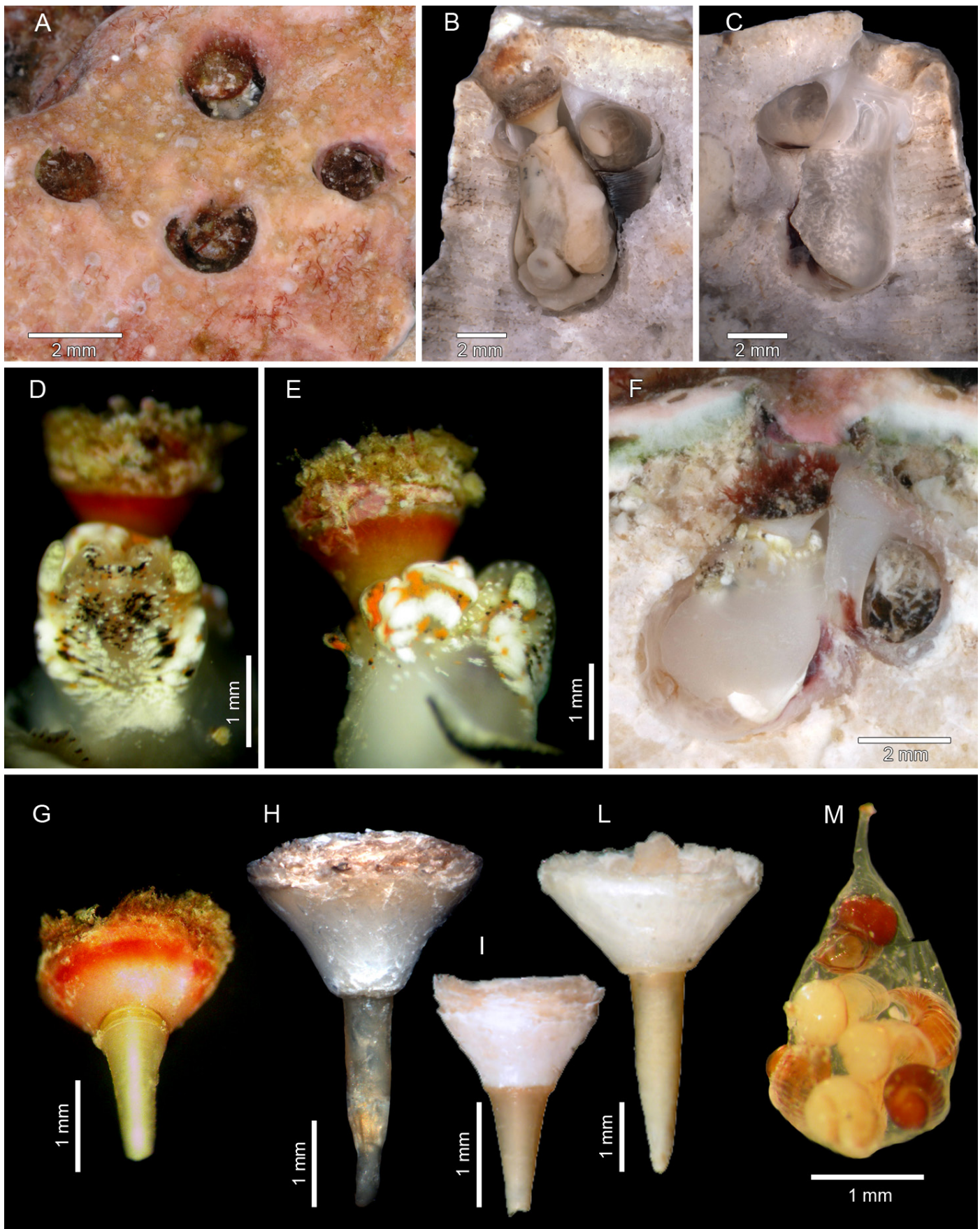

Fig. 1. Novastoa rapaitiensis sp. nov. A. Living specimens embedded in coral substrate with only apertures and heavily encrusted opercula visible (UF 400847, Moorea Island, French Polynesia, photographs by G. Paulay). B-C. Preserved specimen fractured in plane perpendicular to surface, showing both halves of broken shell and animal embedded in coral (UF 436684, Moorea Island, French Polynesia). D-E. Living specimen from Rapa Iti (MNHN IM-2000-31685) just after extraction from the shell. F. Living specimen embedded in coral that has been fractured in plane perpendicular to surface (UF 400849). - G-L. Lateral views of opercula. G. Operculum from Rapa Iti as photographed in the field just after dissection (not from the type series). H. Operculum from the Moorea Island population, French Polynesia (UF 436684). I. Operculum from the Rapa Iti Island population, French Polynesia (MNHN IM-2000-31684). L. Operculum from the Yonge Reef population, Australia (AM C.464342). - M. Egg capsule after removal from interior shell wall (more developed embryos shown in Fig. 2A-D). 

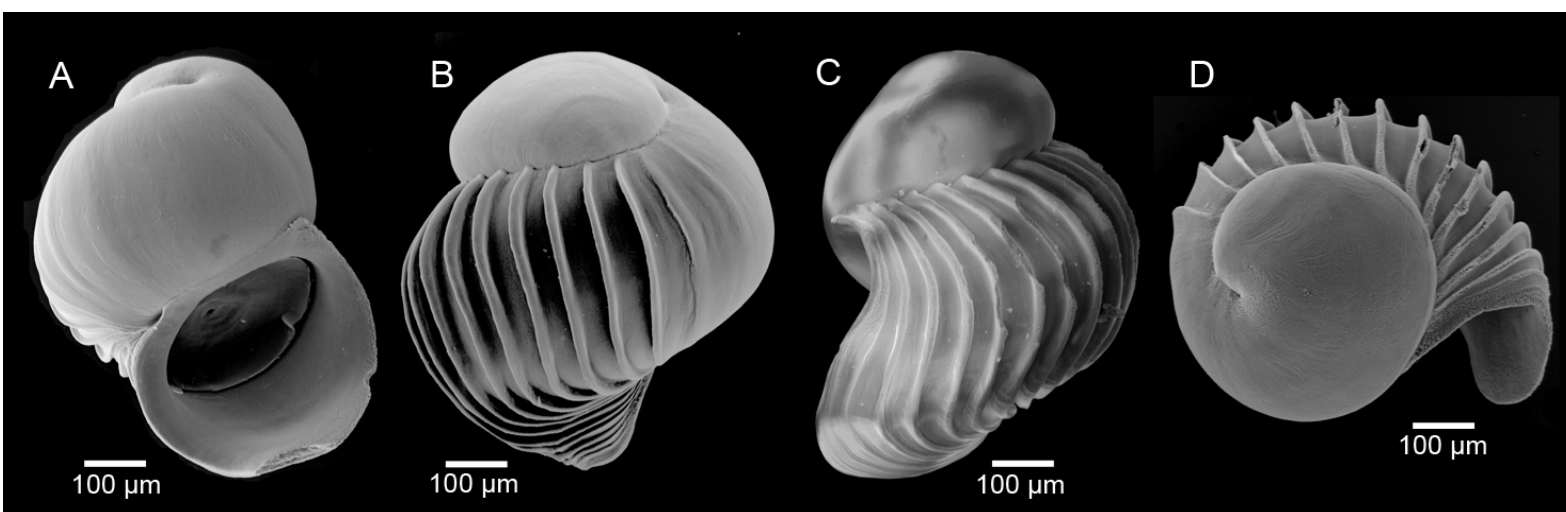

$E$

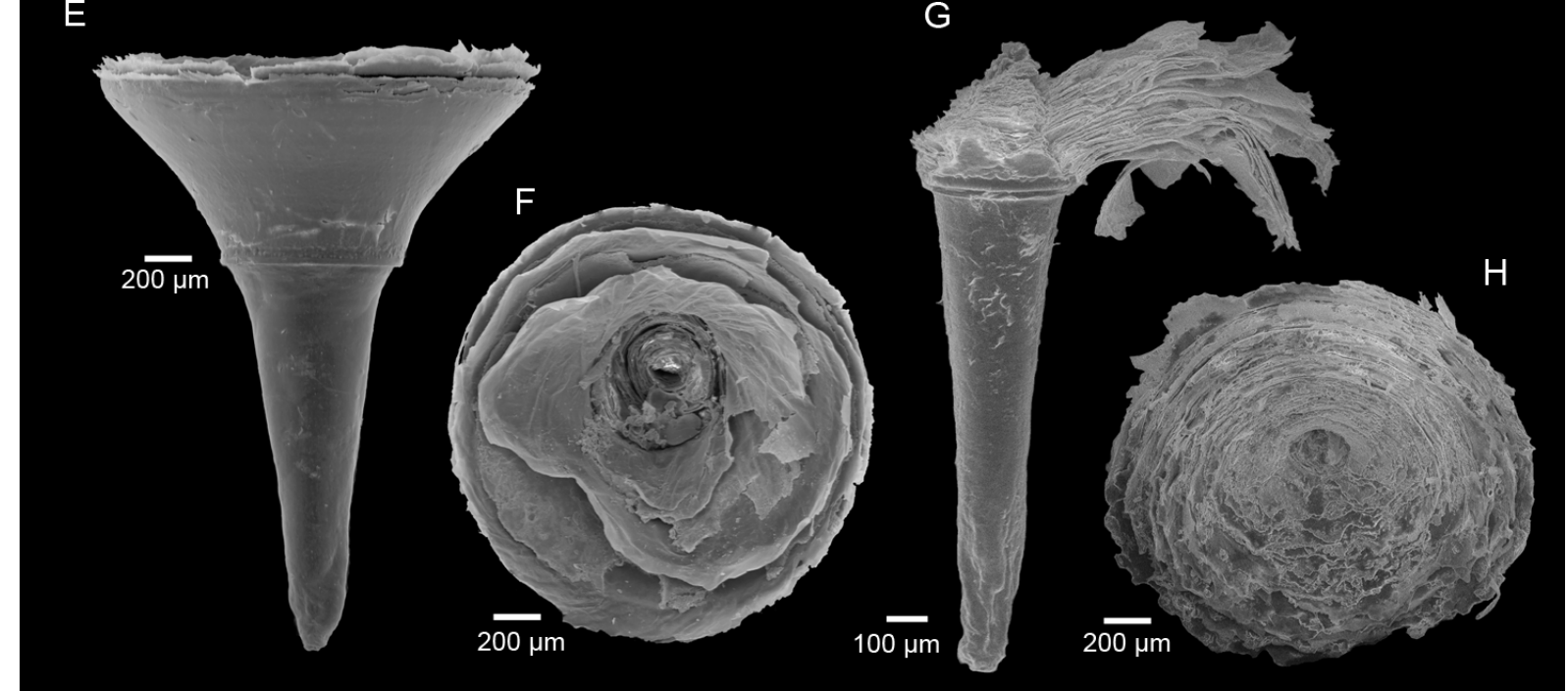

G
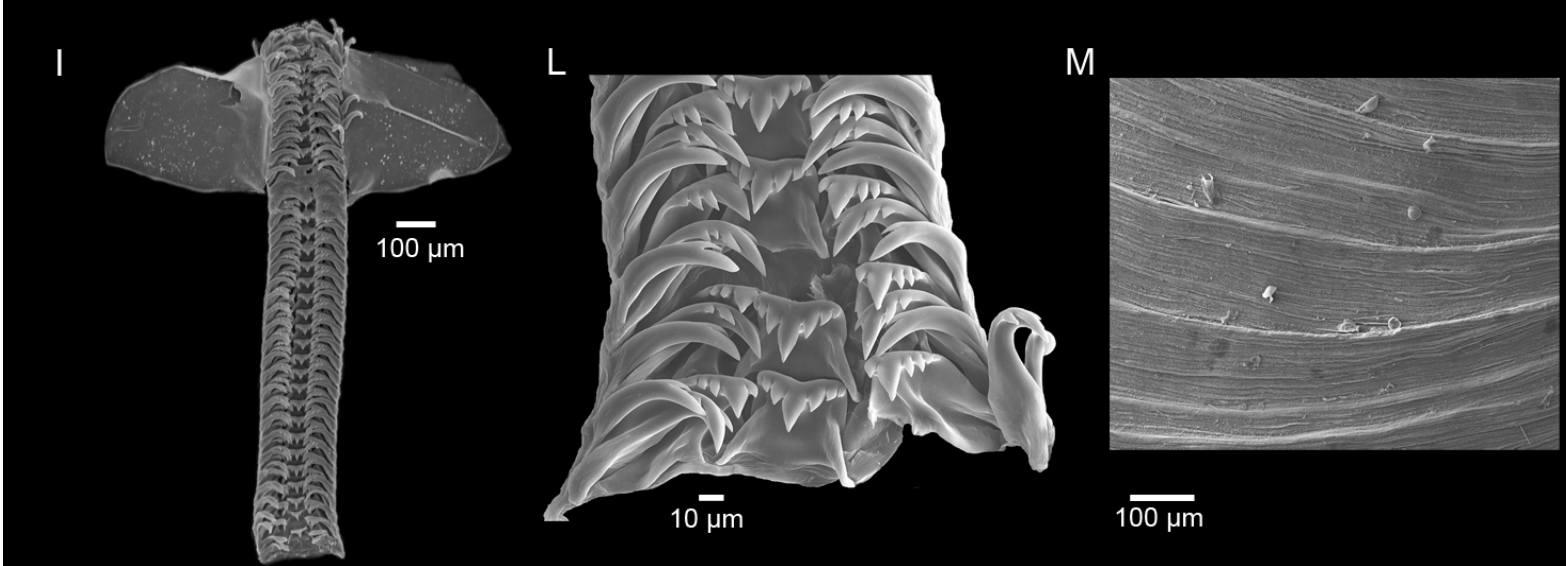

Fig. 2. Novastoa rapaitiensis sp. nov. A-D. Pre-hatching larval shells from egg mass of Fig. 1M. E-F. Operculum of specimen from Rapa Iti (not from the type series). G. SEM image of lateral view of operculum, with lamina stripped away to expose underlying structure (MNHN IM-2000-31684, Rapa Iti Island, French Polynesia). H. SEM image of exterior surface of operculum (MNHN IM-2000-31684, Rapa Iti Island, French Polynesia). I. Radula of specimen from Rapa Iti. L. Central section of radula (MNHN IM-2000-31684, Rapa Iti Island, French Polynesia). M. SEM image of teleoconch sculpture after removal of surrounding substrate (UF 436684, Moorea Island, French Polynesia). 
exterior surface ruffled (Figs 1H-L, 2G-H). Interior surface with very tall, spindle-shaped mammilla, up to $2.3 \mathrm{~mm}$ (Rapa Iti, Fig. 2E), $2.9 \mathrm{~mm}$ (Yonge Reef) or $4 \mathrm{~mm}$ (Moorea) long, golden in color in freshly dissected opercula (e.g., Fig. 1G) from Rapa Iti and Moorea. Opercula heavily encrusted with algae and debris.

Radula (Fig. $2 \mathrm{I}-\mathrm{L}$ ). Length of ribbon up to $1.5 \mathrm{~mm}$, width up to $200 \mu \mathrm{m}$; up to 35 rows. Central tooth with large central cusp, flanked on each side by 3 smaller cusps. Lateral tooth with interlocking grooves for central and marginal teeth; main cusp flanked on outer side by 3 cusps, on inside by 1 cusp. Inner marginal tooth slender, elongate main cusp flanked on outer side by 2 cusps, on inner side by 1 cusp; outer marginal tooth with 1 cusp on inner side, smooth on outside; base straight and simple.

Body external morphology and coloration (Fig. 1B-F). Body length up to $13 \mathrm{~mm}$ (Rapa Iti and Moorea populations) or up to $7 \mathrm{~mm}$ (Yonge Reef population), occupying last whorl of shell. Columellar muscle very short, extending $<0.5$ whorl. Food groove with convoluted flap on outer margin. Adult female mantle divided by pallial notch extending $<0.3$ times mantle length. Color in life (Rapa Iti population): head-foot translucent white overlaid with mottled white, black and orange pigment patches, with black pigment more concentrated in center of head and around lips (Fig. 1D); sides of head behind cephalic tentacles showing large, almost fused, white patches forming a band in continuity with cephalic tentacles, with few orange speckles; side of foot with large orange and white pigment patches (Fig. 1E); cephalic tentacles with yellowish white small patches; mantle edge with a large external band of black pigment. Color in life (Moorea population): head-foot color translucent white overlaid with mottled pale yellow pigment patches around anterior surface of opercular lobe; sides of head with diffuse patches of opaque white pigment; dorsal surface of head around base of tentacles and lips with scattered black and white speckles; cephalic tentacles white; mantle margin opaque white. Color of specimens after preservation in $75-95 \%$ ethanol or formalin: entirely cream with scattered black speckles on dorsal surface of head and mantle margin.

Pallial and Reproductive anatomy (Fig. 3A-F). Gill $0.2 \times$ mantle width; gill leaflets tall, breadth half height; 16 leaflets per mm. Osphradium $3.5 \mathrm{~mm}$ long; margins smooth; anterior tip bent $180^{\circ}$ around columellar muscle. Anus protruding from mantle cavity; fecal pellets cigar-shaped. Hypobranchial gland not discerned. Seminal receptacle attached to tip of proximal diverticulum from pallial oviduct. Male reproductive system not observed.

EGG CAPSULE. A single stalked egg capsule was found attached to the internal side of the shell of a female (Fig. 1M), containing seven embryos close to hatching. In another female a free embryo was found in the mantle cavity. Four of the seven embryos of this egg capsule were prepared for SEM observation (Fig. 2A-D).

\section{Development and ecology}

Adults are common on the reef crest in the wave zone, gregarious but not growing in contact with each other. Some of the specimens collected on Rapa Iti were found on a large dead Acropora coral head at a depth of $30 \mathrm{~m}$, which was not apparently displaced from shallower reef: given these findings the known depth range is 0-30 m. Specimens from Rapa Iti (MNHN IM-2000-31685) and Moorea (UF 400847, Fig. 1A) appear to have grown on dead coral substrates in association with an unidentified species of coralline algae.

\section{Distribution}

Known from the southern central and west Pacific, specifically Rapa Iti Island and Moorea (French Polynesia), and the Great Barrier Reef in Australia. 


\section{Discussion}

Novastoa rapaitiensis sp. nov. resembles the Western Australian species N. batavia Golding, Bieler, Rawlings \& Collins, 2014, as both have a substratum-embedded shell, a tall, conical operculum and similar anatomy. However, $N$. rapaitiensis sp. nov. can readily be distinguished by the remarkably long mammilla on the internal surface of the operculum, a feature unique to this new species. The new species also shares with $N$. pholetor Golding, Bieler, Rawlings \& Collins, 2014 an admixture in egg capsules of dark-colored embryos and white to pale yellow ones (compare Fig. 1M with fig. 228 in Golding et al. 2014). In Novastoa rapaitiensis sp. nov., dark-colored embryos correspond to fully developed ones, while white to pale yellow ones are those less developed, i.e., lacking a complete labrum.

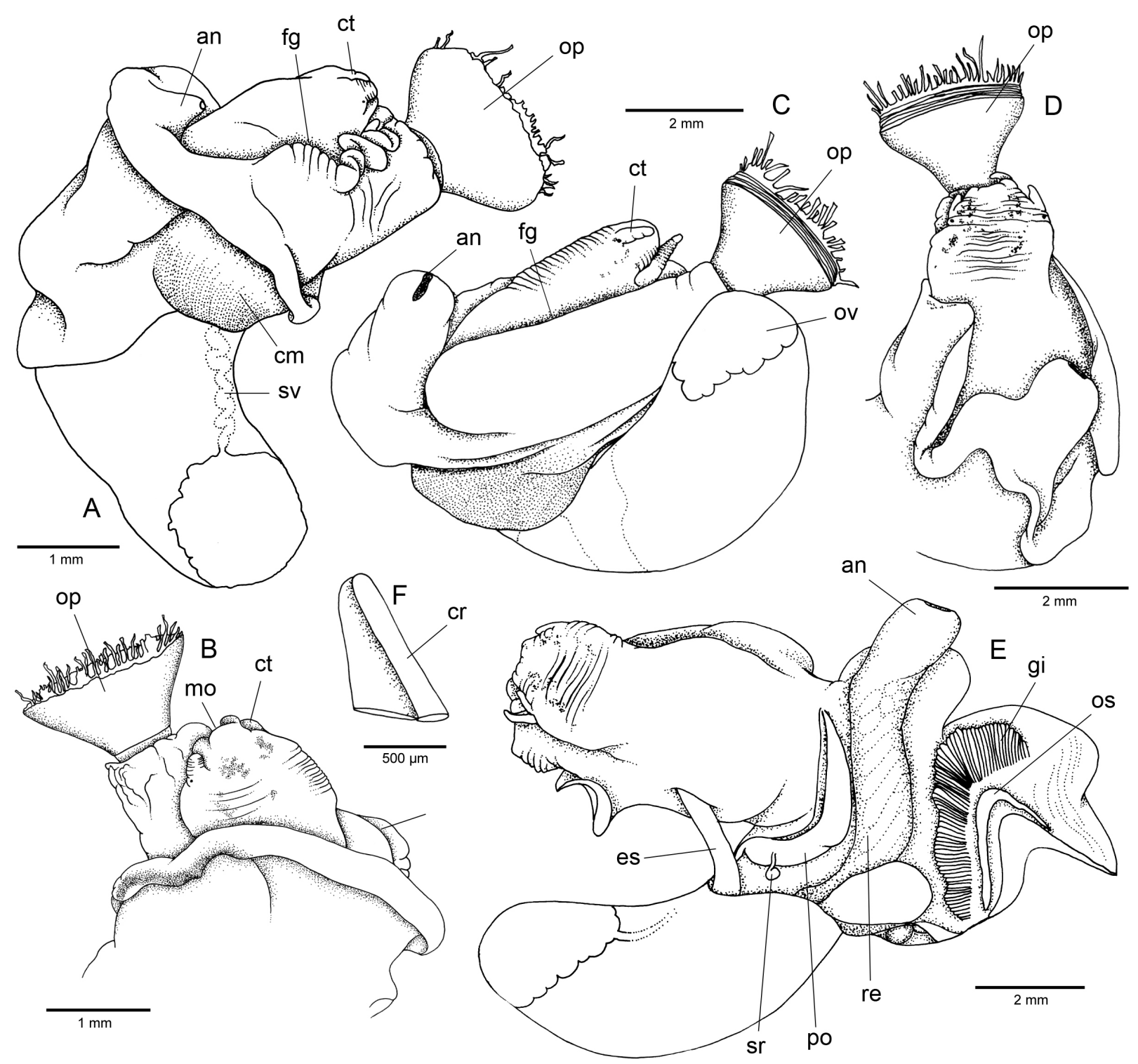

Fig. 3. Anatomy of Novastoa rapaitiensis sp. nov. A-B. Male specimen (holotype, MNHN IM-200027249, Rapa Iti Island, French Polynesia). A. Right view. B. Dorsal view of anterior body. - C. Female specimen, right view (UF 436684, Moorea Island, French Polynesia). - D-E. Female specimen (AM C.464342, Yonge Reef, Australia). D. Dorsal view of anterior body. E. Mantle cavity. - F. Leaflet from mid-section of gill (UF 436684, Moorea Island, French Polynesia). 
Based on a molecular phylogenetic analysis of mitochondrial and nuclear gene regions (Golding et al. 2014), Novastoa rapaitiensis sp. nov. (labeled therein as Novastoa sp., in figs 6 and 171) is strongly supported as a member of the Novastoa clade, and as a sister taxon to a robustly supported lineage containing three other species of Novastoa included in this analysis: N. caboverdensis Golding, Bieler, Rawlings \& Collins, 2014, N. bahamensis Golding, Bieler, Rawlings \& Collins, 2014 and N. pholetor. Inclusion of gene sequences from the two remaining species, Novastoa lamellosa (Hutton, 1873) and $N$. batavia will help to further clarify relationships among extant species of this genus in relation to Novastoa rapaitiensis sp. nov.

Small differences were evident in shell, animal size, operculum profile and soft part coloration between the three populations of Novastoa rapaitiensis sp. nov. studied here. Based on the present state of knowledge, with small sample sizes and patchy geographic sampling, we have considered these differences as intraspecific. We have chosen the holotype from Rapa Iti, because this population was recognized as a new species for the first time in the field during the Rapa 2002 Expedition, and because this is the only site for which molecular sequences and larval features are available, enabling a complete and satisfactory description. The Moorea and Great Barrier Reef populations, which are more than 1200 and $7000 \mathrm{~km}$ distant from Rapa Iti, will need further investigation, and we have therefore excluded specimens from these localities from the type series of the newly described species.

In the few cases in which population-level molecular data are available for vermetids (i.e., Faucci 2007; Calvo et al. 2009, 2015; Golding et al. 2014; Templado et al. 2016), a high level of cryptic diversity has been documented even at much smaller scales. The best-studied example is a Mediterranean reefforming vermetid, usually called Dendropoma petraeum (Monterosato, 1884), which is also one of the most studied vermetids due to its intrinsic potential use as sea level indicator (see Schiaparelli et al. 2006 and references therein). The nominal species was recently shown (Calvo et al. 2009; Templado et al. 2016) to be a complex of four species.

The high level of previously unrecognized 'cryptic' diversity in a semi-enclosed basin, such as the Mediterranean Sea, which longitudinally spans $\sim 4000 \mathrm{~km}$, is remarkable. In the case of N. rapaitiensis sp. nov., much larger distances are involved and ancient dispersal through oceanic barriers might reasonably have been even more complex than that in the Mediterranean area. Divergence time estimates indicated that the ancestral "D. petraeum" diverged into the current four lineages between 9.5 and 4.5 Ma, dates that lie before the Messinian Salinity Crisis, which is believed to have resulted in the extinction of the marine fauna (Calvo et al. 2015). If this model is wrong, i.e., speciation occurred after the Messinian Salinity Crisis, this means that substitution rates of Dendropoma are much higher than usual (Calvo et al. 2015).

This second hypothesis seems to be supported by the high rates of gene rearrangement in mitochondrial DNA observed by Rawlings et al. (2010), which, in turn, could result in long branch attraction (LBA) artifacts for vermetids when this group is included in phylogenetic analyses of Caenogastropoda (e.g., Osca et al. 2015).

Similarly, Faucci (2007) demonstrated strong genetic structure in Dendropoma gregarium Hadfield \& Kay in Hadfield et al., 1972 and D. rhyssoconchum Hadfield \& Kay in Hadfield et al., 1972, two species with direct development among the six studied.

Although there are no detailed ecological studies of larval development available for Novastoa, the size and ornamentation of the protoconchs of Novastoa rapaitiensis sp. nov. (Fig. 2A-D), together with the low number of embryos per capsule, also observed in the other known Novastoa species for which data are available (Golding et al. 2014), seem to suggest direct development. This hypothesis opens new questions about connectivity across the vast Pacific Ocean and the dispersal trajectories for this 
new taxon, whose populations are separated by thousands of kilometers and by complex oceanographic patterns. Additional molecular data will be needed to understand whether the Moorea and Great Barrier Reef populations really belong to the same species or if this would represent another example of cryptic speciation.

\section{Acknowledgements}

We thank the Muséum national d'Histoire naturelle of Paris (MHNN) for having organized and funded the Rapa 2002 Expedition at Rapa Iti and, in particular, Pierre Lozouet (Chef de Mission). We are indebted to Gustav Paulay (UF) for sampling and photographing the Moorea material, and to John Slapcinsky (UF) for the loan of specimens examined in the framework of this study. Funding for this project was provided under US National Science Foundation award DBI-0841760/0841777.

\section{References}

Bieler R. \& Petit R.E. 2011. Catalogue of the Recent and fossil "worm-snail" taxa of the families Vermetidae, Siliquariidae, and Turritellidae (Mollusca: Caenogastropoda). Zootaxa 2948: 1-103.

Calvo M., Templado J., Oliverio M. \& Machordom A. 2009. Hidden Mediterranean biodiversity: Molecular evidence for a cryptic species complex within the reef building vermetid gastropod Dendropoma petraeum (Mollusca: Caenogastropoda). Biological Journal of the Linnean Society 96: 898-912. https://doi.org/10.1111/j.1095-8312.2008.01167.x

Calvo M., Alda F., Oliverio M., Templado J. \& Machordom. A. 2015. Surviving the Messinian salinity crisis? Divergence patterns in the genus Dendropoma (Gastropoda: Vermetidae) in the Mediterranean Sea. Molecular Phylogenetics and Evolution 91: 17-26. https://doi.org/10.1016/j.ympev.2015.05.004

Englund R.A. 2003. Report for the 2002 Pacific Biological Survey, Bishop Museum Austral Islands, French Polynesia expedition to Raivavae and Rapa Iti. Pacific Biological Survey, Constribution 2003004: $1-30$.

Faucci A. 2007. The Influence of Larval Dispersal Potential on Speciation, Phylogeography, and Genetic Population Structure in two Pacific Marine Snail Groups. PhD. Dissertation. University of Hawai'i, USA.

Golding R.E., Bieler R., Rawlings T. \& Collins T.M. 2014. Deconstructing Dendropoma: a systematic revision of a world-wide snail group, with descriptions of new genera (Caenogastropoda: Vermetidae). Malacologia 57: 1-97. https://doi.org/10.4002/040.057.0103

Lozouet P., Cosel R. von, Héros V., Le Goff A., Maestrati P., Menou J.-L., Schiaparelli S. \& Tröndlé J. 2004. L'atelier RAPA 2002 (Polynésie française). Xenophora 107: 17-30.

Lozouet P., Cosel R. von, Héros V., Le Goff A., Maestrati P., Menou J.-L., Schiaparelli S. \& Tröndlé J. 2005. Biodiversity gradient in the Pacific: first results of RAPA 2002 (French Polynesia). In: Richard G. (ed.) Les Mollusques dans la Recherche Actuelle. Actes du III Congrès international des Sociétés européennes de Malacologie (La Rochelle, 24-27 Jun. 2003): 93-99.

Osca D., Templado J. \& Zardoya R. 2015. Caenogastropod mitogenomics. Molecular Phylogenetics and Evolution 93: 118-128. https://doi.org/10.1016/j.ympev.2015.07.011

Rawlings T., MacInnis M., Bieler R., Boore J. \& Collins T. 2010. Sessile snails, dynamic genomes: gene rearrangements within the mitochondrial genome of a family of caenogastropod molluscs. $B M C$ Genomics 11: e440. https://doi.org/10.1186/1471-2164-11-440

Schiaparelli S., Albertelli G. \& Cattaneo-Vietti R. 2006. Phenotypic plasticity of Vermetidae suspension feeding: a potential bias in their use as biological sea-level indicators. Marine Ecology 27 (1): 44-53. https://doi.org/10.1111/j.1439-0485.2006.00076.x 
Templado J., Richter A. \& Calvo M. 2016. Reef building Mediterranean vermetid gastropods: disentangling the Dendropoma petraeum species complex. Mediterranean Marine Science 17: 13-31. https://doi.org/10.12681/mms.1333

Manuscript received: 31 May 2016

Manuscript accepted: 19 September 2016

Published on: 29 May 2017

Topic editor: Rudy Jocqué

Desk editor: Danny Eibye-Jacobsen

Printed versions of all papers are also deposited in the libraries of the institutes that are members of the EJT consortium: Muséum national d'Histoire naturelle, Paris, France; Botanic Garden Meise, Belgium; Royal Museum for Central Africa, Tervuren, Belgium; Natural History Museum, London, United Kingdom; Royal Belgian Institute of Natural Sciences, Brussels, Belgium; Natural History Museum of Denmark, Copenhagen, Denmark; Naturalis Biodiversity Center, Leiden, the Netherlands; Museo Nacional de Ciencias Naturales-CSIC, Madrid, Spain; Real Jardín Botánico de Madrid CSIC, Spain. 